\title{
Partial Protection of Mice against Trypanosoma cruzi after Immunizing with the TcY 72 Antigenic Preparation
}

\author{
Yara M Gomes/ ${ }^{+}$, Frederico GC Abath, Mineo Nakazawa, Paola Minoprio*, \\ Ioannis Vouldoukis**, Loic Monjour**
}

\begin{abstract}
Departamento de Imunologia, Centro de Pesquisas Aggeu Magalhães-Fiocruz, Av. Moraes Rego s/n, Cidade Universitária, 50670-420 Recife, PE, Brasil *Unité de Parasitologie Expérimentale, Institut Pasteur, Paris, France

**Service de Parasitologie et Médecine Tropicale, Groupe Hospitalier Pitié-Salpêtrière, Paris, France
\end{abstract}

A $72 \mathrm{kDa}$ Trypanosoma cruzi glycoprotein recognized by the 164 C11 monoclonal antibody (IgM isotype) was purified by preparative electrophoresis. The antigenic preparation obtained, named TcY 72, was used to immunize C57Bl/10 mice. The following results were observed after immunization: (1) induction of higher titres of IgG than IgM antibodies, as evaluated by indirect immunofluorescence; (2) significant DTH after injection of epimastigotes in mice footpads; (3) peak parasitemia in immunized mice was significantly reduced and animals were negative by 13 days post-infection, although the mice still succumb to infection; (4) the phenotypic analysis of spleen cell populations showed a decrease in the CD4/CD8 ratio in immunized mice. Taken as a whole, these findings indicate that TcY 72 is immunogenic and potentially important for protective immunity.

Key words: Trypanosoma cruzi - immunization - TcY antigenic preparation - Chagas' disease

Chagas' disease, caused by the protozoan Trypanosoma cruzi, is distributed in South and Central America where 18-20 million people are affected (WHO 1991). No vaccine or safe chemotherapy is currently available for the prevention or treatment of this disease, which results in high morbidity of infected individuals. The use of insecticides to control the insect vector is a continuous source of concern because of the impact on the environment. New vaccination strategies for the better control of tropical diseases (Capron \& Dessein 1988) and the recent knowledge of the complexity of parasite antigenic structure and of the immunopathology of the infectious process (Peterson et al. 1986, Choromanski \& Kuhn 1987, Reed 1988) should renew research activity on vaccines against Chagas' disease. Many reports have demonstrated that partial protection of mice against T. cruzi may be induced by immunization with killed (Menezes 1968), attenuated (McHardy \& Elphick 1978), or chemically inactivated (Andrews et al. 1985) parasites. More defined antigens such

This investigation was supported by grants from the Conselho Nacional de Desenvolvimento Científico e Tecnológico-CNPq, Brazil and Economic European Community.

${ }^{+}$Corresponding author. Fax: +55-81-453.1911. E-mail: yara@cpqam.fiocruz.br

Received 9 February 1998

Accepted 2 December 1998 as purified glycoproteins isolated from the epimastigote membrane (Snary 1983), flagellar fraction (Segura et al. 1977, Wrightsman et al. 1995) and exoantigens (Gruppi et al. 1994, 1995) have been shown to have protective potential. The immune mechanisms responsible for resistance are still unclear. However, resistance to infection has been correlated with a decrease in polyclonal lymphocyte responses induced by the parasite (Minoprio et al. 1988).

Recently, we obtained a monoclonal antibody $(\mathrm{mAb})$ 164C11 which was generated from mice immunized with freeze-thawed and sonicated bloodstream trypomastigotes (Y strain) (Gomes et al. 1995). This mAb recognizes a single band with an apparent molecular weight of $72 \mathrm{kDa}$ in Western blots obtained from all developmental stages of T. cruzi (Gomes et al. 1995). Studies using periodate and endoglycosidase treatments suggest that the epitope recognized by this $\mathrm{mAb}$ is not a carbohydrate and seems to be located on the parasite membrane. In addition, the $72 \mathrm{kDa}$ protein seems be involved in adhesion/or internalization of bloodstream trypomastigotes in Vero and macrophage cells (Gomes et al. 1995). In the present report a fraction containing the $72 \mathrm{kDa}$ protein $(\mathrm{TcY}$ 72) was isolated by preparative electrophoresis and its protective potential was evaluated in mice.

\section{MATERIALS AND METHODS}

Parasites - Epimastigote forms of T. cruzi $\mathrm{Y}$ strain, classified as Type I (Andrade 1985) were obtained from acellular cultures as previously de- 
scribed by Gomes et al. (1995), and bloodstream trypomastigotes were obtained from peripheral blood of Swiss-Webster mice acutely infected with the parasite.

Purification of monoclonal antibody - 164C11 hybridoma cells secreting IgM (Gomes et al. 1995) were injected intraperitoneally into pristane-primed $\mathrm{Balb} / \mathrm{c}$ mice. Ascitic fluid was collected 10-14 days later and clarified by centrifugation. The $\mathrm{mAb}$ was purified by gel filtration according to Bouvet al. (1984). The fraction containing IgM was analyzed by SDS-PAGE and Western blot.

Antigenic preparations - The antigenic preparation was obtained by preparative electrophoresis according to the method proposed by Monjour et al. (1988). T. cruzi Y strain epimastigotes were lysed in Laemmli buffer containing protease inihibitors (1 mM PMSF, $0.1 \mathrm{mM}$ EDTA - Sigma Chemical Co., St. Louis, Mo.). The lysates were separated in 10\% SDS-PAGE (Laemmli 1970). The $72 \mathrm{kDa}$ band was removed, sliced and electroeluted according to Andrews (1981). The purity of the electroluted band was analyzed by electrophoresis and the gel was silver-stained by the method of Morrisey (1981).

Western blot - TcY 72 as well as the purified $\mathrm{mAb}$ containing the protease inhibithors $(1 \mathrm{mM}$ PMSF, 0.1 mM EDTA) were solubilized with sample buffer. TcY 72 and the purified mAb were then blotted onto NTC $(0.45 \mathrm{~mm}$ pore size, Bio$\mathrm{Rad}$, Richmond, $\mathrm{Ca}$ ) and the immunoassay performed according to Towbin et al. (1979). The strips containing the $72 \mathrm{kDa}$ protein were incubated with the purified $\mathrm{mAb}$ followed by incubation with horseradish peroxidase-labeled IgM (heavy chain specific). To assess the purity of the purified $m A b$, a direct immunoassay was carried out using several anti-isotypes ( $\mathrm{aIgM}$, a IgA, a IgG1, a IgG2a, a IgG2b, aIgG3 - Caltag). The strips were developed with $0.01 \%$ DAB, $0.01 \% \mathrm{H}_{2} \mathrm{O}_{2}$ in $100 \mathrm{mM}$ PBS pH 7.3.

Mice immunization - Two groups (G1 and GII) of 10 inbred C57B1/10 female mice $(17 \pm 2 \mathrm{~g})$ were used. G1 was injected three times (20 days apart) with $25 \mathrm{mg}$ of TcY 72 subcutaneously. The first injection was emulsified in complete Freund's adjuvant and the following in incomplete Freund's adjuvant. G2, control mice, were injected with the elution buffer and the adjuvants. Five mice of each group were used for evaluation of antibody and delayed hypersensitivity responses and challenge experiments. The remaining five mice were used for the phenotyping of splenic cells.

Antibody response - The antibody response of immunized mice was analyzed by indirect immunofluorescence (IIF) on Y strain formalized epimastigotes (Camargo 1966) seven days after the last boost. Rabbit a-mouse IgG and IgM conjugated to fluorescein were obtained from Sigma.

Delayed-type hypersensitivity test (DTH) DTH test was assayed in each animal 10 days after the last boost of immunization. Epimastigotes in exponential growth were killed by incubation in $1 \%$ buffered formalin and washed five times by centrifugation in $0.15 \mathrm{M} \mathrm{NaCl} \mathrm{pH}$ 7.2. Ten million parasites in $50 \mathrm{ml}$ were injected into the right footpad of each mouse from both immunized and control groups and $\mathrm{NaCl}$ was injected into the contralateral footpad. Swelling in both footpads was measured at 24 and $48 \mathrm{hr}$ with a caliper (MitutoyoJapan). The results were reported as the difference between the swelling of the footpad injected with antigen and the swelling of the footpad injected with diluent.

Infection - Twenty five days after the last boost, the animals were challenged with an intraperitoneal inoculation of $10^{3}$ bloodstream trypomastigotes ( $Y$ strain). Parasitemia was determined by using samples of $5 \mathrm{ml}$ of tail blood as previously described (Brener \& Chiari 1963). Mortality was recorded daily.

Membrane phenotyping of splenic cells - For this study five C57B1/10 female mice were used, as described above and 20 days after the last boost the spleen was removed and collected in a sterile disposable $60 \mathrm{~mm}$ Petri dish containing $5 \mathrm{ml}$ of RPMI 1640 medium (Sigma Chemical Co, St. Louis, Mo). The spleen cells were prepared by gently teasing and isolated by Histopaque- 1077 (Sigma Chemical Co, St. Louis, Mo) density gradient centrifugation. The cells at the ring were collected, washed and suspended in RPMI at a concentration of $10^{6}$ cells $/ \mathrm{ml}$. The cellular suspension $(15 \mathrm{ml})$ was loaded on a glass slide and fixed in acetone. The detection of CD3+ T lymphocytes was performed by direct immunofluorescence with an anti-CD3 mAb (145-2c II, Boehringer Mannheim Biochemicals, Indianapolis, In) conjugated to FITC and diluted 1:40 in PBS pH 7.3. After incubation at $37^{\circ} \mathrm{C}$ for $30 \mathrm{~min}$ with $20 \mathrm{ml}$ of $\mathrm{mAb}$, the cells were washed and observed with a fluorescence microscope. The detection of $\mathrm{CD} 4+$ and CD8+ T lymphocytes was performed by using the avidin-biotin peroxidase system (Kit ABC, Vectastain PK 4002 - Vector Labor, Burlingane) according to the instructions of the supplier using the mAbs anti-CD4 (YTS - 191.1, Cedarlane) or anti-CD8 (53 - 6.7, Boehringer Mannheim Biochemicals, Indianapolis, In).

Statistical analysis - Statistical analysis was performed by using Student's t test (Logiciels: Statgraphics - Statistical Graphics Corporation and Harvard - Microsoft Corporation). 


\section{RESULTS}

Antigenic preparation - The TcY 72 was analyzed by electrophoresis and Western blot. Three polypeptides of 64,72 and $82 \mathrm{kDa}$ appeared on the gel (Fig. 1). This result was unexpected and led us to propose some possible explanations: the 64 and $82 \mathrm{kDa}$ polypeptide may be produced by partial degradation of protein followed by aggregation of the peptide fragments. Some membrane proteins are known to aggregate even in the presence of detergents including SDS (Helenius \& Simons 1975, Dohnal et al. 1980). The fact that the purified $\mathrm{mAb}$ recognizes the polypeptides by Western blot (Fig. 1) supports our explanation. In this assay no reactivity was observed when normal mouse serum was used. However, as the possibility of copurification of other proteins comigrating with the $72 \mathrm{kDa}$ glycoprotein was not excluded we will refer to the purified fraction as TcY 72 antigenic preparation.

Antibody and cellular responses of immunized mice - The anti-T. cruzi antibody response as detected by IIF showed lower titres of IgM antibod-

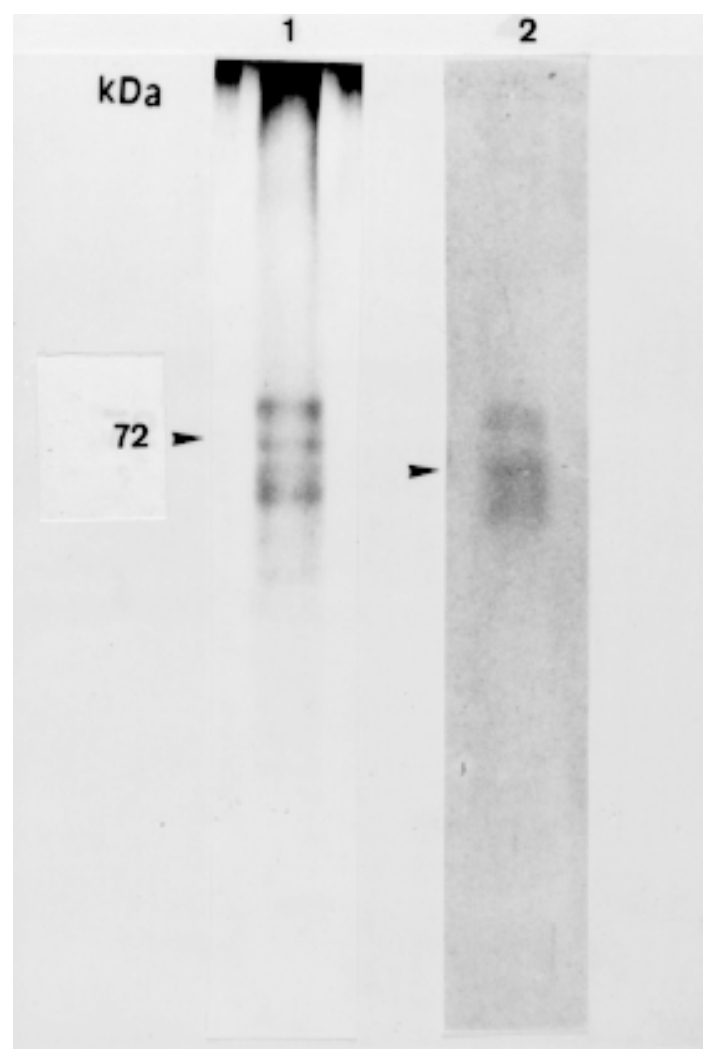

Fig. 1: electrophoresis and Western blot of the TcY 72. (1) Electrophoretic profile after silver staining; (2) antigenic profile after the reaction with the purified mAb. No reaction was evidenced with the mouse normal serum (data not shown). The arrow shows the $72 \mathrm{kDa}$ band. ies in comparison to IgG $(\mathrm{p}<0.025)$ (Table I). IgG and IgM anti-T. cruzi antibodies were not detected in the control. The delayed hypersensitivity reaction was strong when compared to the control. Significant $24 \mathrm{hr}$ swelling $(\mathrm{p}<0.05)$ was present in all immunized mice slightly decreasing by $48 \mathrm{hr}$ (Fig. $2)$. The phenotypic analysis of spleen cell populations at day 20 after the last boost revealed that $\mathrm{CD} 3+\mathrm{T}$ cells $(\mathrm{CD} 4+$ and $\mathrm{CD} 8+)$ increased in numbers when compared to normal mice $(\mathrm{p}<0.01)$. $\mathrm{CD} 8+\mathrm{T}$ cell numbers were higher in the immunized group in comparison to the control $(\mathrm{p}<0.01)$. Although CD4+ T cell numbers were also higher in the immunized group in comparison to the control, this difference was not shown to be statistically significant $(\mathrm{p}=0.17)$ (Table II).

TABLE I

IgG and IgM anti-Trypanozoma cruzi antibody titres of immunized mice ${ }^{a}$

\begin{tabular}{lcc}
\hline & \multicolumn{2}{c}{ Immunoglobulins (Titre ${ }^{-1}$ ) } \\
\cline { 2 - 3 } Mice & $\operatorname{IgG}$ & $\operatorname{IgM}$ \\
\hline 1 & 20 & 5 \\
2 & 40 & 5 \\
3 & 40 & 20 \\
4 & 80 & 20 \\
5 & 80 & 20 \\
\hline
\end{tabular}

a: the sera were collected seven days after the last boost.

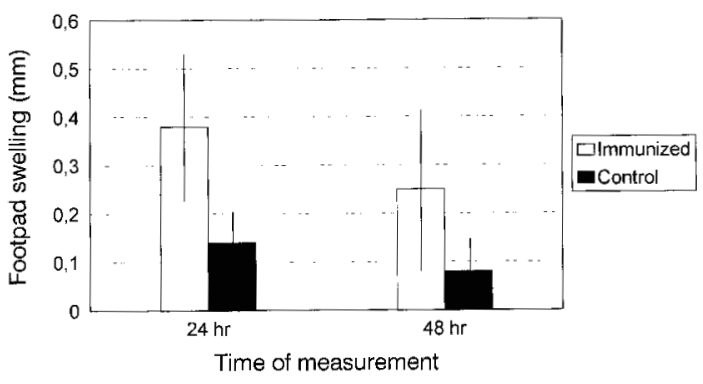

Fig. 2: delayed-type hypersensitivity response in mice immunized with TcY 72 antigen. Each bar respresents the mean $( \pm$ standard deviation) footpad swelling.

\section{TABLE II}

Phenotyping analysis of splenic lymphocytes of mice immunized

\begin{tabular}{lccc}
\hline & \multicolumn{3}{c}{ Lymphocytes (\%) } \\
\cline { 2 - 4 } Mice & CD3+ & CD4+ & CD8+ \\
\hline Immunized & $47.0 \pm 3.2$ & $24.0 \pm 5.6$ & $23.5 \pm 2.1$ \\
Control & $26.5 \pm 2.1$ & $17.0 \pm 1.4$ & $10.0 \pm 1.4$ \\
\hline
\end{tabular}

The results represent the mean \pm standard deviation of five mice. 
Parasitemia and cummulative mortality - The course of parasitemia in immunized mice is shown in Fig. 3. The parasitemia was lower on days 11 after infection $(p<0.05)$ in comparison to non-immunized mice and complete clearance of parasites from the blood was observed by day 13 after challenge. The non-immunized mice developed high parasitemias and $100 \%$ mortality was observed day 11 (Fig. 3). While parasites were cleared by day 13 post-challenge, the immunized mice still succumb to infection by day 22 . Nevertheless, death was significantly delayed in the immunized animals.

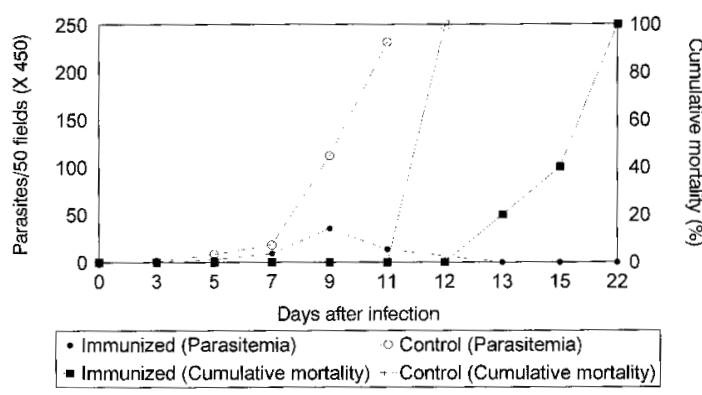

Fig. 3: parasitemia and cumulative mortality of mice after challenge with $10^{3}$ bloodstram trypomastigotes of $\mathrm{Y}$ strain. Each point represents the parasitemia mean of five mice.

\section{DISCUSSION}

In the present report, we analyzed the immunizing potential of the $72 \mathrm{kDa}$ glycoprotein (identified by the $164 \mathrm{C} 11 \mathrm{mAb}$ raised against bloodstream Y strain trypomastigotes) that appears to be located on the parasite membrane and seem to be involved in adhesion or internalization of the parasite (Gomes et al. 1995). This glycoprotein was obtained by preparative electrophoresis and used to immunize C57B1/10 female mice.

Mice immunized with the TcY 72 antigenic preparation developed partial resistance to infection showing lower peak levels of parasitemia and longer survival times than non-immunized mice. These results are relevant if one takes into account that the Y strain used in the challenge is extremely virulent and leads to early death in naive animals (7-12 days post-infection). We are planning to repeat these experiments with a less pathogenic strain of the parasite. The antibody response evaluated by IIF revealed that immunized mouse sera contains $\operatorname{IgM}$ and $\operatorname{IgG}$ antibodies specific for the 72 $\mathrm{kDa}$ glycoprotein. In addition, a strong DTH reaction was observed suggesting that both responses play a role in protective immunity.
It is possible that a $72 \mathrm{kDa}$ glycoprotein identified by a mAb (WIC 29.26) produced against epimastigotes from a Y strain clone (Wel tryp Y2.CL) (Snary et al. 1981) shares similarities with the antigenic structure recognized by the $\mathrm{mAb}$ described here. However, previous results showed that this $72 \mathrm{kDa}$ protein (Snary et al. 1981) failed to induce protection against a $T$. cruzi infection in terms of parasitemia and survival rates. Our results show partial but significant protection when the TcY 72 antigenic preparation is used in our mouse model. We show that mortality is delayed in the immunized group and blood parasitemia is markedly decreased, reduced to undetectable levels by 13 days post-infection. It is not clear why the immunized mice died in the absence of parasitemia. There are two possible explanations: (1) important lesions occurred during the acute phase of the infection; (2) although no parasitemia was detected after 13 days post-infection this would not mean that there are no parasites infecting tissues. Recently, powerful techniques based upon polymerase chain reaction (PCR) detected parasite DNA from inflamatory lesions in human chagasic cardiomyopathy (Jones et al. 1993, Brandariz et al. 1995), even when no parasites could be detected in the blood by conventional examination.

The increase of T CD4+ (although not statistically significant) and T CD8+ T lymphocytes $(p<0.01)$ suggest a role for both cells in the protective response. Indeed, other investigators have already shown that depletion of CD4+ and/or CD8+ $\mathrm{T}$ cells by $\mathrm{mAb}$ treatment in vivo or by genetic deletion of the encoding genes produces mice that are strikingly susceptible to $T$. cruzi infection (Russo et al. 1988, Minoprio et al. 1989, Tarleton 1990). Here we observed a decrease in the CD4/ CD8 ratio in the immunized mice (Table II). The reasons why CD8+ T cell counts were apparently higher in the immunized group in comparison to the control are not clear. However, the induction of CD8+ by immunization with soluble antigen has been demonstrated using several different viral antigens (Schirmbeck et al. 1992, 1994b, Doe et al. 1994), Toxoplasma gondii antigens (Denkers et al. 1993), SDS-denatured ovalbumin (Schirmbeck et al. 1994a) and paraflagellar rod protein (Miller et al. 1997). Particularly similar to our experimental situation was the induction of CD8+ T cells by immunization with paraflagellar rod proteins. Both antigenic preparations were purified by SDS-PAGE (Miller et al. 1997). The relative role of phenotypically different $\mathrm{T}$ cell subpopulations in immunity to T. cruzi has not been well established. However, studies depleting CD8 cells increased susceptibility to infection, resulting in increased parasitemias and mortality (Tarleton 1990). In ad- 
dition, CD8+ T cell depletion also reverses in large part the protective effect resulting from vaccination of mice with paraflagellar rod proteins ((Miller et al. 1997). Cordeiro da Silva et al. (1996) found a high percentage of CD8+ cells in resistant compared to susceptible strains of mice, further supporting a role for $\mathrm{CD} 8+$ cells in protective immunity. The mechanisms by which CD8+ T cells contribute to immunity is not well known. The CD8+ subpopulation of $\mathrm{T}$ cell is the source of lymphokines such as IFN-g which may contribute to the anti-parasite immune response. Another possibility is the protective role of CD8+ cells as cytotoxic T cells, in the T. cruzi infection (Tarleton 1990).

Taken as a whole, these findings indicate that the TcY 72 antigenic preparation is highly immunogenic and potentially important for inducing protective immunity. The $\mathrm{mAb} 164 \mathrm{C} 11$ recognizing a $72 \mathrm{kDa}$ glycoprotein demonstrated a high complement-mediated lytic activity against bloodstream trypomastigotes. In addition, the penetration of bloodstream trypomastigotes in Vero and macrophage cells is partially inhibited by mAb $164 \mathrm{C} 11$ (Gomes et al. 1995). Taken together with the observations that the $72 \mathrm{kDa}$ protein is present in all developmental stages of $T$. cruzi and is recognized by a mAb which has a strong lytic activity against bloodstream trypomastigotes (Gomes et al. 1995) strengthens the idea that this antigen is important for protective immunity against $T$. cruzi infection.

Although immunization with the TcY 72 antigenic preparation has failed to produce complete immunity, we are currently attempting to design better vaccination protocols to improve protection. A vaccine which is capable of reducing acute infection but does not completely eliminate all parasites will only be acceptable if it reduces the incidence and/or severity of chronic Chagas' disease (Scott \& Neal 1984).

\section{ACKNOWLEDGEMENTS}

To Brigitte Guilbert for help with purification of the $\mathrm{mAb}$, Wayner Souza for performing the statistical analysis and Tom Winn for critical reading of the manuscript.

\section{REFERENCES}

Andrade SG 1985. Morphological and behavioural characterization of Trypanosoma cruzi strain. Rev Soc Bras Med Trop 18: 39-46.

Andrews AT 1981. Electrophoresis: theory, techniques, and biochemical and clinical applications, Oxford University Press, New York, 336 pp.

Andrews NW, Alves MJM, Schumacher RI, Colli W 1985. Trypanosoma cruzi: protection in mice immunized with 8-methoxy-psoralen inactivated trypomastigotes. Exp Parasit 60: 255-262.

Bouvet JP, Pires R, Pillot J 1984. A modified gel filtra- tion technique producing an unsual exclusion volume of IgM: a simple way of preparing monoclonal IgM. J Immunol Meth 66: 299-305.

Brandariz S, Schijman A, Vigliano C, Arteman P, Viotti $\mathrm{R}$, Beldjord C 1995. Detection of parasite DNA in Chagas' heart disease. Lancet 346: 1370-1371.

Brener Z, Chiari E 1963. Observations on the chronic phase of experimental Chagas' disease in mice. Rev Inst Med Trop S Paulo 5: 128-132.

Camargo ME 1966. Fluorescent antibody test for the diagnosis of american trypanosomiasis. Technical modification employing preserved culture forms of Trypanosoma cruzi in a slide test. Rev Inst Med Trop $S$ Paulo 8: 227-234.

Capron A, Dessein JP 1988. Vaccination against parasitic infections: some alternative concepts for the definition of protective antigens. Ann Inst Pasteur 139: 109-117.

Choromanski L, Kuhn RE 1987. Use of parasite antigens and interleukin-2 to enhance suppressed immune responses during Trypanosoma cruzi infection in mice. Infect Immun 55: 403-408.

Cordeiro da Silva A, Santos Lima EC, Vicentelli MH, Minoprio P 1996. $\mathrm{V}_{\mathrm{b}}$ 6-bearing T cells are involved in resistance to Trypanosoma cruzi infection in Xid mice. Int Immunol 8: 1213-1219.

Denkers EY, Gazzinelli RT, Hieny S, Caspar C, Sher A 1993. Bone narrow macrophages process exogenous Toxoplasma gondii polipeptides for recognition by parasite-specific cytolytic T lymphocytes. J Immunol 150: 517-526.

Doe B, Steimer SK, Walker CM 1994. Induction of HIVI envelope (gp120)-specific cytotoxic T lymphocytes responses in mice by recombinant $\mathrm{CHO}$ cell-derived gp 120 is enhanced by enzymatic removal of $\mathrm{N}$ linked glycans. Eur J Immunol 24: 2369-2376.

Dohnal JC, Potempa LA, Carvin JE 1980. The molecular weight of three forms of glycophorin A in sodium dodecyl sulfate solution. Biochim Biophys Acta 621: 255-264.

Gomes YM, Abath FGC, Furtado AF, Regis LN, Nakazawa M, Montenegro LT, Vouldoukis I, AlfredMorin C, Monjour L 1995. A monoclonal antibody against blood forms of Trypanosoma cruzi lyses the parasite in vitro and inhibits host cell invasion. Appl Biochem Biotechnol 50: 57-69.

Gruppi A, Cerbán F, Pistoresi-Palencia MC, Votero-Cima E 1995. Trypanosoma cruzi: transfer of protection by lymph node cells obtained from mice immunized with exoantigens of pI 4.5. Exp Parasit 80: 382-389.

Gruppi A, Pistoresi-Palencia MC, Ordoñez P, Cerbán F, Vottero-Cima E 1994. Enhancement of natural antibodies in mice immunized with exoantigens of pI 4.5 from Trypanosoma cruzi. Immunol Lett 42:151-159.

Helenius A, Simons K 1975. Solubilization of membranes by detergents. Biochim Biophys Acta 415: 29-79.

Jones EM, Colley DG, Tostes S, Lopes ER, VnencakJones CL, McCurley TL 1993. Amplification of a Trypanosoma cruzi DNA sequence from inflamatory lesions in human chagasic cardiomyopathy. Am J Trop Med Hyg 48: 348-357. 
Laemmli UK 1970. Cleavage of structural proteins during the assembly of the head of bacteriophage T4. Nature 227: 680-685.

McHardy N, Elphick JP 1978. Immunization of mice against infection with Trypanosoma cruzi. Crossimmunization between five strains of the parasite using freeze-thawed vaccines containing epimastigotes of up to five strains. Int J Parasit 8: 25-31.

Menezes H 1968. Protective effect of an avirulent (cultivated) strain of Trypanosoma cruzi against experimental infection in mice. Rev Inst Med Trop S Paulo 10: $1-4$.

Miller MJ, Wrightsman RA, Stryker GA, Manning JE 1997. Protection of mice against Trypanosoma cruzi by immunization with paraflagellar rod proteins requires T cell, but not B cell function. J Immunol 158: 5330-5337.

Minoprio P, Burlen O, Pereira P, Guilbert B, Andrade L, Hontebeyrie-Joskowicz M, Coutinho A 1988. Most B Cells in acute Trypanosoma cruzi infection lack parasite specificity. Scand J Immunol 28: 553-561.

Minoprio P, Itohara S, Heusser C, Tonegawa S, Coutinho A 1989 . Immunobiology of murine $T$. cruzi infection: the predominance of parasite non-specific responses and the activation of TCRI T cells. Immunol Rev 112: 183-207.

Monjour L, Vouldoukis I, Ogunkolade WB, Frommel D 1988. Perspectives de vaccination antileishmanienne. Conférence Nationale des Vétèrinaires Spécialisés en Petits Animaux, Paris (Suppl. 5): 133-141.

Morrissey JH 1981. Silver stain for proteins in poliacrylamide gels: a modified procedure with enhanced uniform sensitivity. Analit Biochem 117: 307-568.

Peterson DS, Wrightsman RA, Manning JE 1986. Cloning of a major surface antigen gene of Trypanosoma cruzi and identification of a nonapeptide repeat. Nature 322: 566-568.

Reed SG 1988. In vivo administration of recombinant IFN-gamma induces macrophages activation, and prevents acute disease, immune suppression, and death in experimental Trypanosoma cruzi infection. J Immunol 140: 4342-4347.

Russo M, Starobinas N, Coutinho A, HontebeyrieJoskowicz M 1988. Parasitic load increases and myocardial inflamation decreases, in $T$. cruzi-in- fected mice after inactivation of helper T cells. Ann Inst Pasteur Immunol (Paris) 139: 225-236.

Schirmbeck R, Bohm W, Reimann J 1994a. Injection of detergent-denatured ovalbumin primes murine classe I-restricted cytotoxic T cells in vivo. Eur J Immunol 24: 2068-2072.

Schirmbeck R, Melber K, Mertens T, Reimann J 1994b. Antibody and cytotoxic T-cell responses to soluble hepatitis B virus (HBV) S antigen in mice: implication for the pathogenesis of $\mathrm{HBV}$-induced hepatitis. J Virol 68: 1418-1425.

Schirmbeck R, Zerrahn J, Kuhrober A, Kury E, Deppert W, Reimann J 1992. Immunization with soluble simiam virus 40 large $\mathrm{T}$ antigen induces a specific response of $\mathrm{CD}^{+} \mathrm{CD}^{-} \mathrm{CD}^{+}$cytotoxic $\mathrm{T}$ lymphocytes in mice. Eur J Immunol 22: 759-766.

Scott MT, Neal RA 1984. The vaccine potential of cell surface glycoproteins from Trypanosoma cruzi. Phil Trans $R$ Soc Lond 307: 63-72.

Segura EL, Vazques G, Bronzina A, Campos JM, Cerizola JA, Gonzalez-Cappa SM 1977. Antigens of the subcellular fractions of Trypanosoma cruzi: II. Flagellar and membrane fraction. J Protozool 24: 540-543.

Snary D 1983. Cell surface glycoprotein of Trypanosoma cruzi: protective immunity in mice and antibody levels in human chagasic sera. Trans $R$ Soc Trop Med Hyg 77: 126-129.

Snary D, Ferguson MAJ, Scott MT Allen AK 1981. Cell surface antigens of Trypanosoma cruzi: use of monoclonal antibodies to identify and isolate an epimastigote specific glycoprotein. Biochem Parasit 3: 343-356.

Tarleton R 1990. Depletion of CD8+ T cells increases susceptibility and reverses vaccine-induced immunity in mice infected with Trypanosoma cruzi. $J$ Immunol 144: 717-724.

Towbin H, Staehelin T, Gordon J 1979. Electrophoretic transfer of proteins from polyacrylamide gells to nitrocellulose sheets: procedure and some applications. Proc Nat Acad Sci 76: 4350-4354.

WHO - World Health Organization 1991. Control of Chagas' disease. Technical Report Series 11.

Wrightsman RA, Miller MJ, Saborio JL, Manning JE 1995. Pure paraflagellar rod protein protect mice against Trypanosoma cruzi infection. Infect Immun 63: $122-125$. 